\title{
IMPLEMENTASI NILAI NILAI FIQH SIYASAH DALAM PERATURAN DAERAH (PERDA) SYARI'AH
}

\author{
Wahyu Abdul Jafar \\ IAIN Bengkulu \\ Jln. Raden Fatah Pagar Dewa Kota Bengkulu \\ Email:wahyujabar@gmail.com
}

\begin{abstract}
This scientific work was made to find out the implementation of siyasa law fiqh on shari'a regulations. This study is very important because the Syari'ah Regional Regulation which is made without regard to the values contained in fiqh of siyasah will dry up and lose its Islamic spirit. Even the law that is born can actually create injustice and prosperity if it is later applied in the community. After the researcher carried out the study in depth it was found a conclusion that the Sharia law that had implemented the value of the siyasah included Syari'ah Perda that was oriented and obedient to Islamic Shari'a, the Syari'ah Regional Regulation which was oriented to the benefit of the the value of justice and equality of rights, the Shari'a Regional Regulation that avoids elements of persecution and dignity, and the Shari'a Regional Regulation which is based on the principle of deliberation.
\end{abstract}

Keywords: Fiqh Siyasah; Regional Regulation; Syari'ah

\begin{abstract}
Abstrak: Karya ilmiah ini dibuat untuk mengetahui implementasi nilai nilai fiqh siyasah yang terdapat pada perda syari'ah. Kajian ini penting sekali dilakukan karena Perda syari'ah yang dibuat tanpa memperhatikan nilai nilai yang terkandung pada fiqh siyasah akan kering dan kehilangan spirit keislamannya. Hukum yang terlahirpun bisa saja malah membuat ketidakadilan dan kemakmuran jika nanti diterapkan di masyarakat. Sehinga perlu adanya formulasi yang jitu dalam memadukan unsur fiqh siyasah dan peraturan daerah yang dibuat oleh pemerintah setempat. Setelah peneliti melakukan kajian secara mendalam didapati sebuah kesimpulan bahwa perda syaria'h yang sudah menerapkan nilai nilai siyasah antara lain Perda Syari'ah yang berorientasi dan patuh terhadap syariat islam, Perda Syari'ah yang berorientasi pada kemaslahatan, Perda Syari'ah yang berorientasi pada nilai nilai keadilan dan persamaan hak, Perda Syari'ah yang menghindari unsurunsur penganiayaan dan kedoliman, serta Perda syari'ah yang didasarkan pada prinsip musyawarah.
\end{abstract}

Kata kunci: Fiqh Siyasah; Peraturan Daerah; Syari'ah 
AL-IMARAH: Jurnal Pemerintahan dan Politik Islam

Vol. 4, No. 1, 2019

\section{Pendahuluan}

Peraturan daerah (Perda) Syari'ah saat ini menarik perhatian masyarakat untuk diperbincangkan, dikarenakan salah satu partai politik (PSI) menyatakan tidak mendukung adanya peraturan daerah (Perda) yang bernuansa syaria'ah. ${ }^{1}$ Alasan tidak mendukung yang dilontarkan oleh ketua PSI ini menjadi kontroversi ditengah tengah masyarakat. Pasalnya, alasan PSI menolak perda syari'ah dikarenakan perda syari'ah menurut ketua PSI dalam penerapanya menimbulkan ketidak adilan bagi kaum minoritas.

Alasan ini menimbulkan polemik ditengah masyarakat dan berbuntut dilaporkanya ketua PSI ke bareskim Polda Metro Jaya. ${ }^{2}$ Hal ini terjadi karena, banyak yang mengangap pernyataan ketua PSI sebagai bentuk penistaan terhadap agama Islam. Alasan yang dilontarkan Ketau PSI menyingung perasaan kaum muslimin sebagai

\footnotetext{
${ }^{1}$ Pada HUT PSI ke-4, Grace mengatakan PSI akan mencegah diskriminasi dan tindakan intoleransi. Selain itu, menurut Grace, saat ini tidak boleh lagi ada penutupan rumah ibadah secara paksa. "PSI akan mencegah lahirnya ketidakadilan, diskriminasi, dan seluruh tindak intoleransi di negeri ini," kata Grace di ICE BSD Hall 3A, Tangerang, Minggu (11/11)." Partai ini tidak akan pernah mendukung perda Injil atau Perda Syariah, tidak boleh lagi ada penutupan rumah ibadah secara paksa," https://news.detik.com, diakses pada tanggal 22 April 2019

${ }^{2}$ Surat tanda terima laporan tercatat di Sentra Pelayanan Kepolisian Terpadu (SPKT) Bareskrim Polri dengan Nomor STTL/1217/XI/2018/BARESKRIM. Adapun, nomor Laporan Polisi (LP) tersebut, yakni LP/B/1502/XI/2018/BARESKRIM tertanggal 16 November 2018.Penulis : Reza Jurnaliston, Editor Sabrina Asril, Artikel ini telah tayang di Kompas.com dengan judul "Grace Natalie Dilaporkan ke Bareskrim Polri terkait Penistaan Agama". https://nasional.kompas.com, diakses pada tanggal 22 April 2019

mayoritas di indonesia seolah ajaran agama islam adalah ajaran yang sewenang wenang dan bersifat penindasan.

Akibat polemik ini, Majlis Ulama Indonesia (MUI) angkat bicara menyatakan bahwa keberadaan Perda syari'ah sebenarnya tidak seperti yang dibayangkan oleh kelompok yang menolak adanya perda syari'ah, bahkan adanya perda syari'ah sebenarnya untuk menguatkan fungsi pancasila. ${ }^{3}$ Sehinga tidak benar jika dikatakan perda syari'ah mendeskritkan kelompok minoritas. Hadirnya perda syari'ah ini menguatkan sila ke-lima pancasila berbunyi keadilan sosial bagi seluruh rakyat indonesia. Selain itu, Perda syari'ah hadir juga untuk menguatkan moral bangsa indonesia yang saat ini mulai terjadi gradasi (penurunan) moral. MUI menegaskan hadirnya perda syari'ah akan memperkuat undang undang yang selama ini sudah dibuat oleh pemerintah.

Untuk memperjelas polemik kontrovesi perda syari'ah ini, penulis akan menuturkan secara detail posisi perda syari'ah dalam bingkai fiqh siyasah. Penulis akan mengkaji apakah Pembuatan perda syari'ah sudah sesuai dengan fiqh siyasah ataukah belum, dimana tujuan utama dari fiqh siyasah

3 SEKRETARIS Jenderal Majelis Ulama Indonesia (MUI) Anwar Abbas menilai tak masalah ada peraturan daerah (perda) yang mengambil dasar hukum dari nilai-nilai agama Islam. Bentuknya tak harus dengan Perda Syariah. Anwar mengatakan Indonesia telah bersepakat dengan Pancasila sebagai landasan. Merujuk sila pertama, Ketuhanan Yang Maha Esa, agama bisa menjadi sumber nilai dalam perundangan. http://mediaindonesia.com, diakses pada tanggal 22 April 2019 
adalah tahqiqul maslahah wa dar'ul mafasid (mewujudkan kemaslahatan dan menolak kemudhorotan). Sehinga logikanya tidak mungkin hukum yang terlahir dari perda syari'ah akan menimbulkan kemudhortan jika sudah sesuai dengan fiqh siyasah.

\section{Pengertian Fiqh Siyasah}

Secara etimoligi, istilah fiqh siyasah “ الفقه "السياسي " terdiri dari dua kata, yakni kata fiqh dan al-siyasi (الفقه) (السياسي). Kata fiqh sendiri secara bahasa berarti faham dan mengetahui. Makna ini diambil dari ayat Al-Qur'an, ${ }^{4}$

\section{قالوا يا شعيب ما نفقه كثيرا مما تقول}

Artinya "kaum berkata: Wahai Syu'aib, kami tidak memahami banyak dari apa yang kamu bicarakan”. (QS. Al-Hud: 11)

Sedangakan menurut terminologi, istilah fiqh memiliki makna:

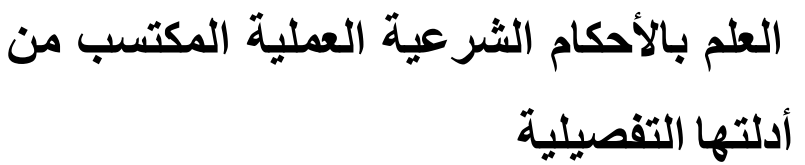

Artinya "Fiqh adalah mengetahui hukumhukum syariat yang bersifat amaliah (Praktis) yang digali dari dalil-dalilnya secara terperinci", 5

Adapun istilah al-siyasi, secara bahasa berasal dari lafadz "ساس - يسوس - سياسة" yang memiliki arti mengatur (أمر/دبّر). diambil dari hadis:

${ }^{4}$ Wahbah al-Zuhaylî, Ushûl al-Fiqh al-`Islâmî (Damaskus: Dâr al-Fikr, 2001) vol. 1, h. 18

${ }^{5}$ Wahbah al-Zuhaylî, Ushûl al-Fiqh al-'Islâmî (Damaskus: Dâr al-Fikr, 2001) vol. 1, h. 19

${ }^{6}$ Abdul Wahab Khalaf, al siyasah syar'iyyah aw nidzham al dawlah al islamiyyah (Al Kaherah: Dar al Anshar, 1977), h. 5.

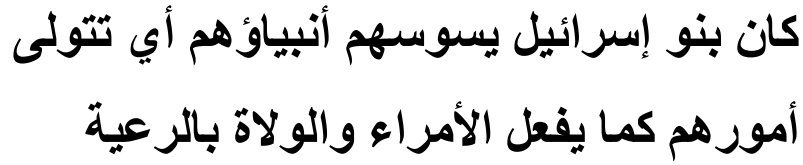

Artinya: "Adanya Bani Israil itu diatur oleh nabi-nabi mereka, yaitu nabi mereka memimpin permasalahan mereka seperti apa yang dilakukan pemimpin pada rakyatnya".

Contoh lain yang menunjukan makna mengatur adalah seperti berikut ini

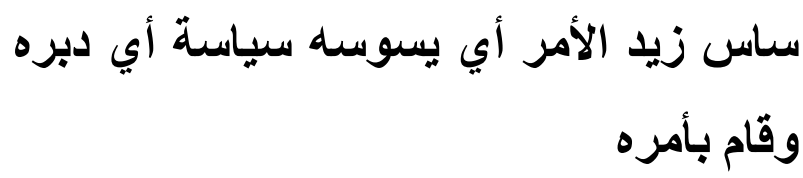

Artinya: "Zaid mengatur sebuah perkara, maksudnya Zaid mengatur dan mengurusi perkara tersebut". ${ }^{7}$

Mashdar lafadz al-siyasi adalah siyasah yang memiliki bermakna:

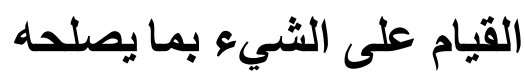

Artinya "bertindak pada sesuatu dengan apa yang patut untuknya". 8

Apabila kedua lafadz fiqh dan al-siyasi digabungkan maka akan menjadi fiqh siyasah atau yang dikenal juga dengan istilah siyasah syar'iyyah. Fiqh Siyasah sendiri menurut terminoligi memiliki beberapa makna, antara lain:

1. Menurut Imam al-Bujairimi, yang dimaksud dengan fiqh siyasah adalah "memperbagus permasalahan rakyat dengan cara mengatur dan memerintah mereka dengan tujuan membuat maslahah

\footnotetext{
${ }^{7}$ Mujar Ibnu Syarif \& Khamami Zada, Fiqh Siyasah (Erlangga, 2008), h. 10

8 Ahmad Sukardja, Hukum Tata Negara \& Hukum Administrasi Negara Dalam perspektif Figh Siyasah, (Sinar Grafika, 2012), h. 9.
} 
untuk mereka sendiri. Kemaslahatan ini terwujud dengan sebab ketaatan mereka terhadap pemerintahan". 9

2. Menurut Wuzarat al-Awqaf wa al-Syu'un, yang dimaksud dengan fiqh siyasah adalah "memperbagus kehidupan manusia dengan cara mengatur permasalahan mereka dan menunjukkan jalan yang dapat menyelamatkan mereka dari kehancuran, baik pada waktu sekarang ataupun waktu akan datang". 10

3. Menurut Imam Ibn 'Abidin, yang dimaksud dengan fiqh siyasah adalah "mewujudkan kemaslahatan manusia dengan cara menunjukkannya kepada jalan yang bisa menyelamatkan, baik di dunia maupun di akhirat. Sumbernya Siyasah berasal dari Nabi Muhammad SAW., baik secara khusus maupun secara umum, baik secara lahir, maupun secara batin. Dari sisi lahir, siyasah berasal dari para sultan (pemerintah). Sedangkan secara batin, siyasah berasal dari para ulama yang menjadi pewaris Nabi Muhammad. $^{11}$

Secara sekilas antara Fiqh Siyasah dan Politik terlihat hampir sama. Persamaan ini terlihat dari dua unsur yang terdapat pada keduanya, yakni Pihak yang mengatur dan Pihak yang diatur. Kedua unsur ini adalah

9 Djazuli, Fiqh Siyasah, (Prenanda media, 2003), h. 2

${ }^{10}$ Ali Syariati, Imamah dan Umamah, Terj. Afif Muhammad (Mizan, 1989), h. 44

11 Ali Syariati, Imamah dan Umamah, Terj. Afif Muhammad (Mizan, 1989), h. 46 86 unsur yang sangat penting dan bersifat timbal balik, baik dalam Fiqh Siyasah maupun dalam ilmu politik. Menurut Prof. H. A. Djazuli, Fiqh Siyasah mirip dengan Politik, karena ada dua unsur penting dalam bidang politik, yaitu negara yang perintahnya bersifat eksklusif dan unsur masyarakat, yang diatur atau diperintah. Sekalipun memiliki persamaan diantara Fiqh Siyasah dan Politik, namun bila dicermati secara mendetail, sebenarnya diantara keduanya terdapat perbedaan yang mendasar dari sisi segi fungsinya, fiqh siyasah berbeda dengan politik. Menurut Ali Syariati, fiqh siyasah (siyasah syar'iyyah) tidak hanya menjalankan fungsi pelayanan (khidmah) saja, tetapi juga pada saat yang sama menjalankan fungsi pengarahan ('ishlah). Sebaliknya, politik dalam arti yang murni hanya menjalankan fungsi pelayanan, tanpa menjalankan fungsi pengarahan (`ishlah). Hal ini bisa dibuktikan dengan melihat definisi politik di terdapat dalam Penguin Encyclopedia: ${ }^{12}$

"Political Science: The academic discipline which describes and analyses the operations of government, the state, and other political organizations, and any other factors which influence their behaviour, such as economics. A major concern is to establish how power is exercised, and by whom, in resolving conflict within society."

12 Abd al Rahman Taj, Al Siyasah al Syar'iyyah wa al Fiqh al Islami (Matba'ah Dar al Ta'lif, 1953), h. 7-21 
Definisi diatas, ternyata tidak menyinggung sama sekali istilah kemaslahatan untuk rakyat atau masyarakat secara umum dalam politik. Perbedaan anatara fiqh siyasah dan politik tersebut tampak terlihat juga dalam persoalan, fiqh siyasah harus terikat dan senantiasa sesuai dengan syariat Islam, atau sekurang-kurangnya sesuai dengan pokokpokok syariah yang kulli, baik yang tertuang di dalam Al-Qur'an maupun hadis Nabi Muhammad SAW, Maqashid al-syari'ah, Kaidah-kaidah usul fiqh serta cabangcabangnya. Sehinga agar politik bisa diterima dalam fiqh siyasah harus berupa politik yang didasari adat istiadat atau doktrin Islam (siyasah wadl'iyyah) yang tidak bertentangan dengan prinsip Islam. ${ }^{13}$

\section{Pengertian Perda Syariah}

Secara etimologi perda syari'ah terdiri dari dua kata, yakni perda dan syari'ah. Yang dimaksud dengan perda disini adalah peraturan daerah baik yang dibuat oleh pemerintah provinsi maupun pemerintah kabupaten/kota. Sedangkan yang dimaksud dengan syari'ah adalah

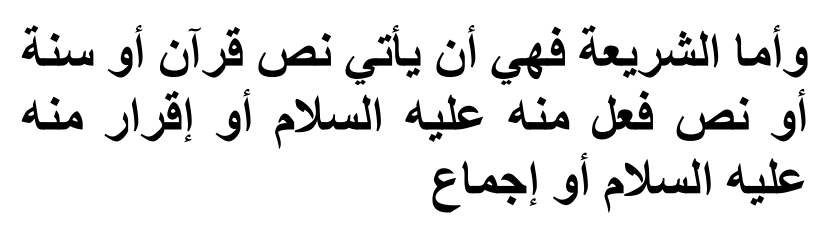

Artinya, "Syariat adalah segala aturan yang didalamnya terdapat teks yang jelas dari AlQuran, teks sunah (hadits), teks yang didapat April 2019 dari perbuatan Nabi SAW, teks yang didapat dari taqrir (ketetapan) Nabi SAW, dan ijma' para sahabat. ${ }^{14}$

Berdasarkan teks diatas dapat dipahami bahwa yang dimaksut dengan syari'ah adalah segala aturan hidup manusia yang bersumber dari teks yang terdapat dalam Al-Quran, hadits Nabi SAW, dan ijma' para sahabat.

Menurut Dani Muhtada, Ph.D, Dosen Fakultas Hukum Universitas Negeri Semarang yang meraih gelar S3 dari Northern Illinois University, Amerika Serikat, dengan judul disertasi "The Mechanisms of Policy Diffusion: A Comparative Study of Shari'a Regulations in Indonesia" (Mekanisme Penyebaran Kebijakan: Studi Perbandingan Perda-Perda Syariah di Indonesia), Perda Syariah adalah "setiap peraturan yang dikeluarkan oleh pemerintah daerah yang secara langsung maupun tidak langsung terkait, atau setidak-tidaknya dianggap terkait, dengan hukum atau norma-norma keIslaman". ${ }^{15}$

Definisi ini mengisyaratkan bahwa apa yang disebut dengan perda syariah cakupanya tidak mesti bermuatan syari'ah saja namun bisa berisi hal -hal yang tidak ada kaitanya dengan syari'ah secara langsung namun masih memiliki korelasi didalamnya pun masih bisa disebut perda syari'ah.

14 Ibnu Hazm, Al-Ihkam fi Ushulil Ahkam, (Beirut: Darul Afaq, 2001), juz III, h. 137

15 Dani Muhtada, Ph.D, Makalah ini disampaikan dalam orasi ilmiah dalam rangka Dies Natalis VII Fakultas Hukum Universitas Negeri Semarang pada tanggal 4 Desember 2014 di Semarang. 
Menurut Mohamad Guntur Romli, larangan kegiatan Ahmadiyah atau sekte-sekte antara perda syari'ah dan syari'ah itu sendiri Muslim yang dianggap sesat lainnya. Keenam, adalah dua hal yang berbeda, sehinga tidak boleh disamakan antara keduanya. Syariah adalah hukum suci dan abadi langsung dari Allah Swt. Syariah sifatnya suci, mutlak, tidak ada diskusi dan abadi. Sedangkan Perda yang dibuat oleh para politisi dan birokrasi (bukan ulama ahli) yang di sana ada motif kekuasaan dan elektoral (ingin dipilih) ada dalam ranah "politik kekuasaan”, Perda bisa tidak didukung, bisa direvisi, bisa ditolak, bisa dibatalkan. $^{16}$

\section{Kategorisasi Perda Syari'ah}

Menurut Dani Muhtada, Ph.D, setidaknya ada tujuh kategori perda syari'ah yang ada di Indonesia. Pertama, perda syari'ah yang berkaitan dengan moralitas. Perda Ini meliputi perda tentang pelarangan minuman keras, prostitusi, dan perjudian. Kedua, perda syari'ah yang berkaitan dengan kebijakan zakat, infaq, dan shadaqah. Ketiga, perda syari'ah yang berkaitan dengan pendidikan Islam. Perda ini meliputi perda tentang madrasah diniyah dan baca tulis Al-Quran. Keempat, perda syari'ah yang berkaitan dengan pengembangan ekonomi Islam. Perda ini mencakup perda tentang Baitul Mal wat Tamwil (BMT) dan Bank Perkreditan Rakyat Syariah (BPRS). Kelima, perda syari'ah berkaitan dengan keimanan seorang Muslim. Contoh Perda ini adalah perda tentang

16 http://www.gunromli.com, diakses pada tanggal 21 April 2019 
3. Undang-Undang/Peraturan Pemerintah Pengganti Undang-Undang;

4. Peraturan Pemerintah;

5. Peraturan Presiden;

6. Peraturan Daerah Provinsi; dan

7. Peraturan Daerah Kabupaten/Kota.

Peraturan Daerah (Perda) Provinsi sendiri adalah Peraturan Perundang-undangan yang dibentuk oleh Dewan Perwakilan Rakyat Daerah (DPRD) Provinsi dengan persetujuan bersama Gubernur daerah tersebut. ${ }^{18}$ Sedangkan yang dimaksud dengan Peraturan Daerah Kabupaten/Kota adalah Peraturan Perundang-undangan yang dibentuk oleh Dewan Perwakilan Rakyat Daerah (DPRD) Kabupaten/Kota dengan persetujuan bersama Bupati/Walikota daerah tersebut. ${ }^{19}$

Obyek kajian atau materi muatan dalam Peraturan Daerah (Perda) Provinsi dan Peraturan Daerah (Perda) Kabupaten/Kota hanya berisi materi muatan yang diadakan dalam rangka penyelenggaraan otonomi daerah, tugas pembantuan serta menampung kondisi khusus daerah tersebut. Selain itu juga bisa berupa materi muatanyang menjadi lanjutan penjabaran Peraturan Perundangundangan yang lebih tinggi. ${ }^{20}$

Dalam undang undang peraturan pemerintah pasal 9 dijelaskan bahwa pengaturan mengenai Urusan Pemerintahan terbagi menjadi tiga, yaitu: a. urusan pemerintahan absolut, adalah urusan pemerintahan yang sepenuhnya menjadi kewenangan pemerintah pusat. Urusan pemerintahan absolut meliputi: politik luar negeri, pertahanan, keamanan, yustisi, moneter/ fiskal nasional dan agama. $^{21}$

yang dimaksud dengan "urusan agama" disini misalnya menetapkan hari libur keagamaan yang berlaku secara nasional, memberikan pengakuan terhadap keberadaan suatu agama, menetapkan kebijakan dalam penyelenggaraan kehidupan keagamaan, dan sebagainya.

b. urusan pemerintahan konkuren, adalah urusan pemerintahan yang dibagi antara pemerintah pusat dan daerah provinsi dan daerah kabupaten/kota, urusan pemerintahan konkuren yang diserahkan ke daerah menjadi dasar pelaksanaan otonomi daerah; dan

c. urusan pemerintahan umum, adalah urusan pemerintahan yang menjadi kewenangan presiden sebagai kepala pemerintahan.

Pemerintah pusat sendiri dalam menyelenggarakan urusan pemerintahan absolut membagi menjadi dua, yakni:

a. melaksanakan sendiri; atau

b. melimpahkan wewenang kepada instansi vertikal yang ada di daerah atau gubernur sebagai wakil pemerintah pusat berdasarkan asas dekonsentrasi. ${ }^{22}$ Yang

\footnotetext{
${ }^{21}$ Pasal 10 ayat (1) UU Pemerintahan Daerah

${ }^{22}$ Pasal 10 ayat (2) UU Pemerintahan Daerah
}

\footnotetext{
${ }^{18}$ Pasal 1 angka 7 UU 12/2011

${ }^{19}$ Pasal 1 angka 8 UU 12/2011

${ }^{20}$ Pasal 14 UU 12/2011
} 
AL-IMARAH: Jurnal Pemerintahan dan Politik Islam

Vol. 4, No. 1, 2019

dimaksud dengan asas dekonsentrasi adalah pelimpahan sebagian Urusan Pemerintahan yang menjadi kewenangan Pemerintah Pusat kepada gubernur sebagai wakil Pemerintah Pusat, kepada instansi vertikal di wilayah tertentu, dan/atau kepada gubernur dan bupati/wali kota sebagai penanggung jawab urusan pemerintahan umum. $^{23}$

Kewenangan urusan agama pada awalnya merupakan kewenangan pemerintah pusat yang termasuk urusan pemerintahan absolut, nyatanya dimungkinkan untuk dilimpahkan wewenangnya kepada instansi vertikal yang ada di daerah atau gubernur sebagai wakil pemerintah pusat berdasarkan asas dekonsentrasi. ${ }^{24}$

\section{Implementasi Nilai- Nilai Fiqh Siyasah Dalam Perda Syari'ah}

Dalam pembuatan perda syari'ah harus memperhatikan beberapa hal penting agar tidak membentur sisi fiqh siyasah, antara lain:

\section{Perda Syari'ah harus berorientasi dan patuh terhadap syariat islam}

Setiap aturan yang terlahir dari Perda Syari'ah harus sesuai dengan konsep konsep yang telah digariskan oleh Syari'at Islam. Apabila ada aturan yang bertentangan dengan syari'at maka aturan ini batal demi hukum. Prinsip ini lahir dari Qur'an Surat Al-Ahzab ayat 36 ,

\footnotetext{
${ }^{23}$ Pasal 1 angka 9 UU Pemerintahan Daerah

${ }^{24} \mathrm{https}: / / \mathrm{www} \cdot h u k u m o n l i n e . c o m$, diakses pada tanggal 21 April 2019

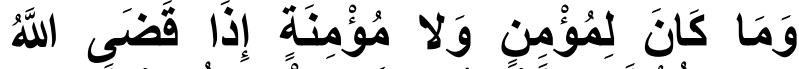

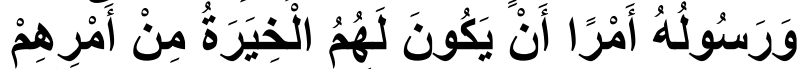

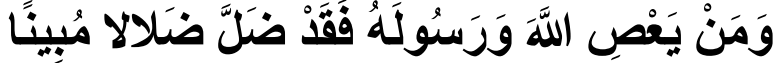
Artinya: "Dan tidaklah patut bagi laki-laki mukmin dan tidak (pula) bagi perempuan mukminah, apabila Allah dan Rasul-Nya telah menetapkan suatu ketetapan, akan ada bagi mereka pilihan (yang lain) tentang urusan mereka. Barang siapa mendurhakai Allah dan Rasul-Nya, sungguh dia telah sesat dengan kesesatan yang nyata.” (QS. al-Ahzab: 36)

Perda syari'ah yang melahirkan kepatuhan total terhadap Allah SWT. Inilah yang akan membawa keberkahan dan kemaslahatan suatu negeri. Jika rakyat suatu negara mau mengikuti aturan main yang telah digariskan oleh Allah untuk mengatur jalan kehidupan mereka maka daerah tersebut akan mendapatkan janjinya Allah berupa dibukakanya keberkahan dilangit dan dibumi. Hal ini sebagai mana firman Allah dalam surat A'raf ayat 96,

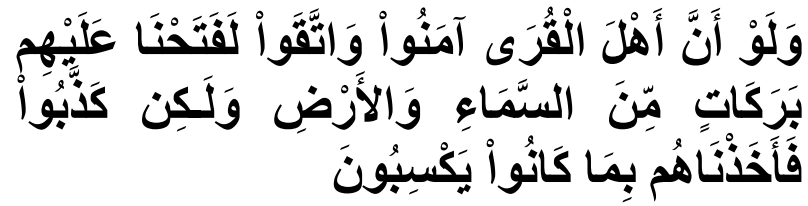

Artinya: “Jikalau sekiranya penduduk negerinegeri tersebut beriman dan bertaqwa, pastilah Kami akan melimpahkan kepada mereka berkah dari langit dan bumi, tetapi mereka mendustakan (ayat-ayat Kami) itu, maka Kami siksa mereka disebabkan perbuatannya." (QS: Al-A'raf: 96)

Dengan demikian kunci dari segala keberkahan dan kesuksesan pembangunan suatu daerah adalah terletak pada seberapa 
patuhnya penduduk daerah tersebut taat dan patuh kepada Allah SWT.

\section{Perda Syari'ah harus berorientasi pada kemaslahatan}

Tujuan paling mendasar dibuatnya suatu hukum (maqosidus syariah) adalah untuk mewujudkan kemaslahatan dan menolak kemudhorotan. Seluruh hukum yang terlahir dari perda syaria' harus bisa mewujudkan kemaslahatan ketika hukum tersebut diterapkan di masyarakat. Hal ini sesuai dengan kaedah fiqh,

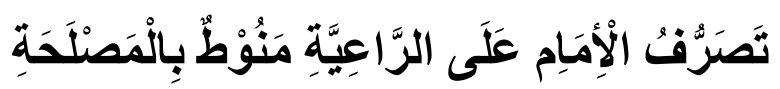
Artinya: "Tindakan imam terhadap rakyatnya harus dikaitkan dengan kemaslahatan."

Kebijakan yang dibuat oleh seorang pemimpin, yang dalam hal ini berupa perda syari'ah harus berpihak dan menguntungkan kepada rakyat. Bahkan jika didalam suatu kebijkan yang akan dibuat nanti terdapat unsur mafsadat, maka perlu dipertimbangkan besaran unsur mafsadatnya, jika ternyata lebih banyak mudhorot ketimbang manfaatnya maka kebijakan seperti ini perlu dibatalkan. Hal ini sesuai dengan kaedah fiqh,

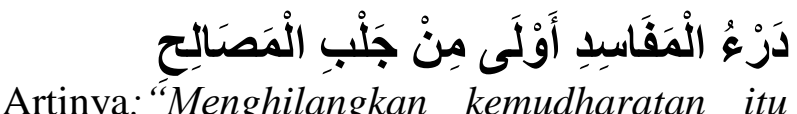
lebih didahulukan daripada Mengambil sebuah kemaslahatan."

Kemaslahatan dan kemudhorotan disini (perda syari'ah) tidak hanya bersifat duniawiyat saja, melainkan mencakup juga urusan urusan akhirat. Hal ini diperkokoh dengan pendapat imam Asy-Syathibi, yang tertera dalam kitab al-Muwwafaqat:

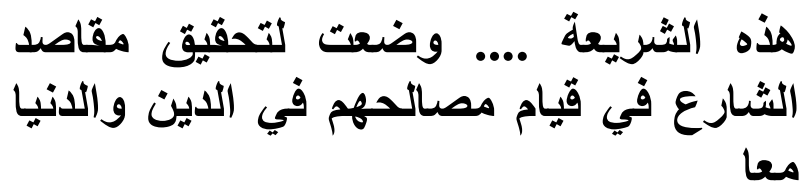

Artinya: Sesungguhnya syariat itu ditetapkan bertujuan untuk tegaknya (mewujudkan) kemashlahatan manusia di dunia dan Akhirat secara bersama sama".

Aturan yang terlahir dari perda syari'ah harus bisa mewujudkan dua sisi kemaslahatan ini secara bersama sama tidak boleh timpang salah satu sisinya. Kesinergian antara maslahat dunia dan akhirat merupakan tujuan utama yang harus dicapai. Bahkan Rosul sendiri pun diutus menjadi rahmat bagi alam semesta (baik alam dunia maupun alam akhirat).

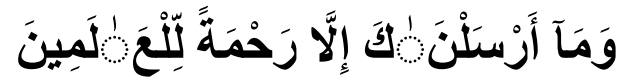

Artinya: Dan tiadalah kami mengutus kamu, melainkan untuk (menjadi) rahmat bagi semesta alam. (QS. Al-Anbiya: 107)

Lafadz 'Alamin merupakan kalimat jamak (plural) yang memiliki arti alam (yang banyak) dan termasuk juga didalamnya alam dunia dan alam akhirat yang semuanya mendapatkan rahmat sebab diutusnya Nabi Muhammad.

Dalam ayat yang lainnya Allah ta'ala berfirman:

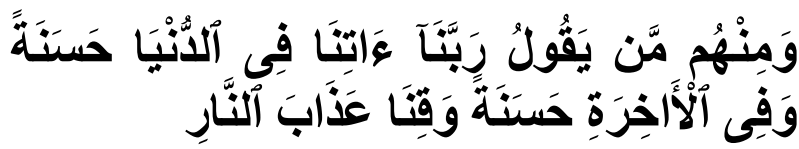

Artinya: Dan di antara mereka ada orang yang berdoa: "Ya Tuhan kami, berilah kami kebaikan di dunia dan kebaikan di akhirat dan 
peliharalah kami dari siksa neraka". (QS. AlBaqarah: 201-202)

Pada ayat diatas diketahui bahwa hasanat (kebaikan) itu ada dua, yakni hasat fi dunya (kebaikan didunia) dan hasanat fil akhirot (kebaikan di akhirat). Ini menunjukan bahwa yang dikejar dalam perda syari'ah bukan hanya sisi maslahat dalam urusan dunia semata namun juga harus baik dalam sisi akhiratnya juga.

Perda Syari'ah harus berorientasi pada nilai nilai keadilan dan persamaan hak

Supremasi hukum yang berlandaskan pada nilai nilai keadilan dan persamaan hak mutlak menjadi prinsip yang harus ada didalam fiqh siyasah. Prinsip ini pun harus ada juga dalam perda syari'ah. Hal ini juga sudah dicontohkan langsung oleh Rosulloh SAW., dalam sabdanya yang diriwatkan melalui jalur sanad Dari Sayyidah 'Aisyah radhiyallahu 'anha,

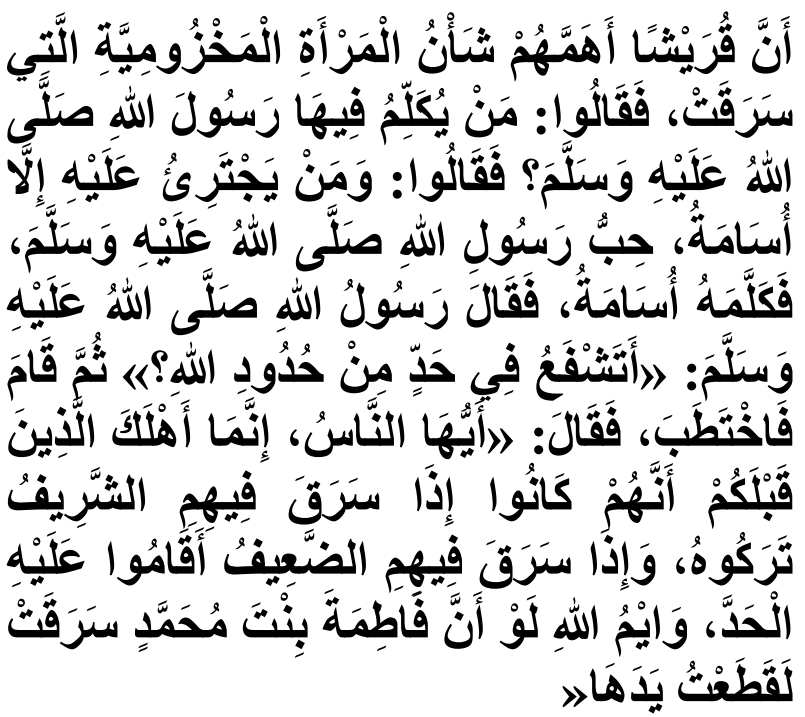

Artinya: "Sesungguhnya orang-orang Quraisy mengkhawatirkan keadaan (nasib) wanita dari bani Makhzumiyyah yang (kedapatan) mencuri. Mereka berkata, 'Siapa yang bisa melobi rasulullah shallallahu 'alaihi wa sallam?' Mereka pun menjawab, 'Tidak ada yang berani kecuali Usamah bin Zaid yang dicintai oleh rasulullah shallallahu 'alaihi wa sallam.' Maka Usamah pun berkata (melobi) rasulullah shallallahu 'alaihi wa sallam (untuk meringankan atau membebaskan si wanita tersebut dari hukuman potong tangan). Rasulullah shallallahu 'alaihi wa sallam kemudian bersabda, 'Apakah Engkau memberi syafa'at (pertolongan) berkaitan dengan hukum Allah?' Rasulullah shallallahu 'alaihi wa sallam pun berdiri dan berkhutbah, 'Wahai manusia, sesungguhnya yang membinasakan orang-orang sebelum kalian adalah jika ada orang yang mulia (memiliki kedudukan) di antara mereka yang mencuri, maka mereka biarkan (tidak dihukum), namun jika yang mencuri adalah orang yang lemah (rakyat biasa), maka mereka menegakkan hukum atas orang tersebut. Demi Allah, sungguh jika Fatimah binti Muhammad mencuri, aku sendiri yang akan memotong tangannya", (HR. Bukhari no. 6788 dan Muslim no. 1688).

Dalam Fiqh Siyasah urusan keadilan dan persamaan hak merupakan hal yang tidak bisa ditawar tawar lagi. Bahkan Rosulluloh SAW., menjelaskan awal kehancuran suatu bangsa apabila penegakan hukumnya tebang pilih, antara yang kaya dan yang miskin dibedakan, antara orang yang berpangkat dan orang yang biasa dibedakan. Hukum tajam kebawah tapi tumpul keatas. Dalam islam 
konsep persamaan hukum sangat dijunjung sekali, siapapun dia seberapapun kayanya, apabila bersalah maka akan dihukum sesuai aturannya.

Setiap kebijakan atau aturan yang dibuat dari perda syari'ah harus bernafaskan dengan nilai nilai keadilan dan dilaksanakan dengan penuh amanah. Hal ini sebagaimana firman Allah SWT. dalam surat an-Nisa ayat 58 ,

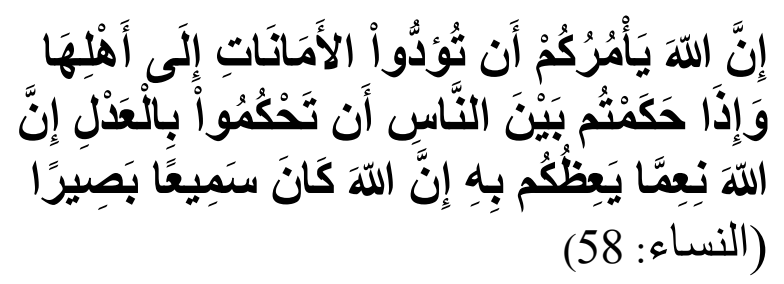

Artinya: "Sesungguhnya Allah menyuruh kamu menyampaikan amanat kepada yang berhak menerimanya, dan (menyuruh kamu) apabila menetapkan hukum di antara manusia supaya kamu menetapkan dengan adil. Sesungguhnya Allah memberi pengajaran yang sebaik-baiknya kepadamu. Sesungguhnya Allah adalah Maha mendengar lagi Maha melihat."

Dalam ayat ini, Allah menjelaskan kepada kita bahwa fiqh siyasah yang harus diterapkan oleh seorang kholifah $^{25}$ Allah dimuka bumi ini adalah sistem siyasah yang dibangun dengan nilai nilai amanah dan keadailan. Seorang pemimpin atau kholifah harus menjadikan nilai amanah dan keadilan

${ }^{25}$ Khalifah secara etimologi berasal dari kata khalafa-yakhlufu, yang memiliki beberpa pengertian, mengganti, memberi ganti dan menempati tempatnya . Kata khalifah mempunyai makna pengganti atau penguasa. Ahmad Warson Munawwir, kamus alMunawwar,( Surabaya : pustaka progressif), h. 362 dalam setiap kebijakan yang dibuat oleh nya. Setiap tugas yang dibebankan kepadanya harus diselesaikan dengan penuh rasa tangung jawab tanpa membeda bedakan orang atau golongan tertentu yang berkaitan dengan kebijakan yang ia buat. Kebijakan yang dibangun tanpa dilandasi dengan keadilan dan responbility (amanah) akan sia sia tidak akan bisa membawa kemakmuran dan kesuksesan sebagus apapun kebijakan tersebut dibuat.

Nilai nilai fiqh siyasah yang harus ada pada perda syari'ah selanjutnya adalah keadilan. seorang pemimpin harus bisa berlaku adil dalam membuat kebijakan yang dituangkan dalam perda syari'ah. Kebijakan atau aturan yang dibuat harus bisa mengcover seluruh kepentingan dari rakyat yang dipimpinnya walaupun tetap mengacu pada secala prioritas mana yang lebih maslahah. Rasullah SAW., sendiri memberikan jaminan kepada pemimpin yang bisa berlaku adil dalam kepemimpinanya, ia akan mendapatkan naungan langsung dari Allah SWT., pada hari kiamat kelak. Hal ini sebagaimana sabda beliau yang diriwayatkan oleh Imam Bukhori,

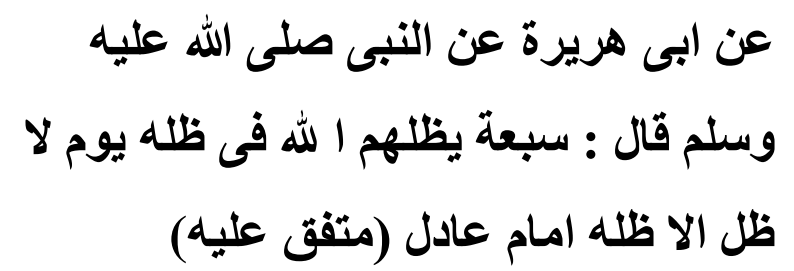

Artinya: "Dari Abu Hurairah rodiyollohuanhu, telah bersabda Rasulullah SAW, ada tujuh golongan yang dinaungi Allah SWT, dibawah naungan-Nya, pada hari kiamat yang tidak ada 
naungan kecuali naungan-Nya, yang pertama adalah imam yang adil...,26

Dalam hadis ini, Rosulloh SAW., menjelaskan bahwa pemimpin yang adil akan mendapatkan naungan pada hari kiyamat dimana tidak ada naungan selain dari Allah SWT., ini menujukan bahwa berlaku adil dalam kepemimpinan manfaatnya tidak hanya pada orang yang dipimpin saja melainkan sang pemimpin sendiri bisa mendapatkan manfaatnya juga. Kepemimpinan ${ }^{27}$ adil yang dicontohkan oleh Rosulluloh SAW., kemudian diikuti juga oleh para khalifah rosidin

Perda Syari'ah harus menghindari unsurunsur penganiayaan dan kedoliman

Rekayasa dalam Perda Syari'ah harus sangat dihindari, karena rekayasa hukum ini akan menimbulkan kedholiman dan penganiayaan ditengah tengah masyarakat. Upaya rekayasa hukum ini sering juga disebut dengan istilah hilah. Islam sangat mengharamkan sekali sifat hilah yang

\footnotetext{
${ }^{26}$ Imam Bukhori, Shohih Bukhori, Maktabah Syamilah, Juz 6, h. 2496

${ }^{27}$ Syarat-Syarat Kepemimpinan menurut AlMawardi dalam kitabnya al-akham al-sultoniyah ada tujuh antara lain :a) Adil,b) Memilki pengetahuan yang membuatnya mampu berijtihad di dalam berbagai kasus dan hukum,c) Memiliki pancaindra yang sehat, baik telinga, mata maupun mulut sehingga ia dapat secara langsung menangani persoalan yang diketahui. d) Memilki organ tubuh yang sehat dan terhindar dari cacat yang dapat menghalanginya dari menjalankan tugas dengan baik dan cepat. e) Memliki gagasan, yang membuatnya mampu memimpin rakyat dan mengurusi berbagai kepentingan. f) Memilki keberanian dan sifat kesatria yang membuatnya mampu melindungi negara dan melawan musuh.g) Memilki nasab dari silsilah suku Quraisy berdasarkan nash dan Ijma'. Imam almawardi, Al-Ahkam Ash-sulthaniyah ( sistem pemerintahan khalifah islam ), (Qisthi Prres; Jakarta), h.

melahirkan kedholiman dan aniyaya. Hal ini sebagaimana sabda Nabi Muhammad SAW., yang diriwayatkan oleh Abu Dzar Al-Ghifari,

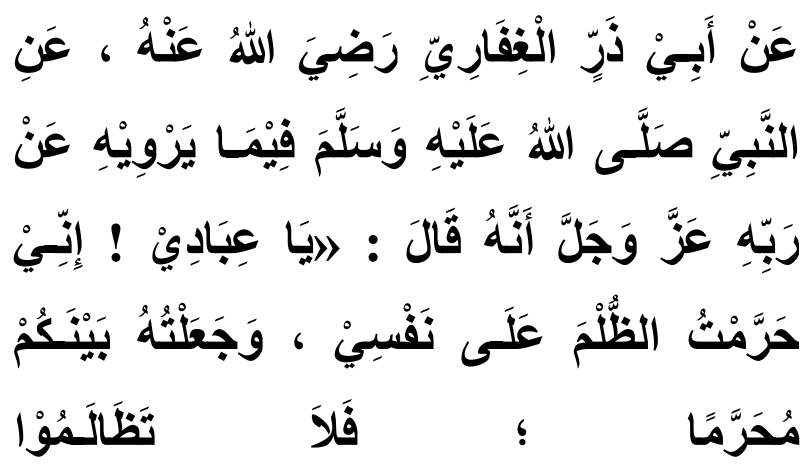

Artinya: Dari Abu Dzar al-Ghifâri Radhiyallahu anhu bahwa Nabi Shallallahu 'alaihi wa sallam meriwayatkan firman Allah Azza wa Jalla , "Wahai hamba-Ku! Sesungguhnya Aku mengharamkan kezhaliman atas diri-Ku dan Aku menjadikannya haram di antara kalian. Maka, janganlah kalian saling menzhalimi. (HR. Imam Muslim). ${ }^{28}$

Perda syari'ah harus didasarkan pada Prinsip musyawarah

Setiap masalah yang muncul dalam setiap kebijakan yang dibuat harus diselesaikan dengan jalan musyawaroh jangan diputuskan oleh dirinya saja meskipun ia menjadi seorang pemimpin. Dalam pembuatan perda syari'ah pun harus dilakukan secara bersama sama dengan jalan musyawarah mufakat. Sehinga bisa meminimalisir terjadinaya kesalahan dalam pembuatan kebijakan yang dituangkan pada perda

28 Imam Muslim, Shohih Muslim, Maktabah Syamilah 14 G, Jus 4, h.1994 
syari'ah. Nilai musyawarah dalam setiap urusan ini terdapat dalam surat as-Syuro ayat 38 ,

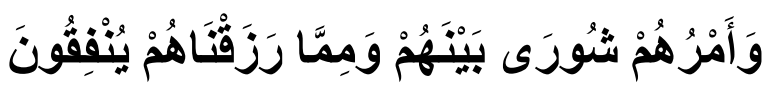

Artinya: "Urusan mereka (diputuskan) dengan musyawarat antara mereka dan dari apa apa yang telah kami rezqikan kepada mereka nafkahkan".

Dalam ayat ini Allah SWT. Menjelaskan kepada kita bahwa segela persoalan yang muncul dalam setiap kebijakan yang menyangkut hajat hidup kaum muslimin harus diselesaikan dengan jalan musyawaroh, berdiskusi bersama mencari solusi terbaik. Bukan dengan cara suara voting suara terbanyak, karena terkadang suara mayoritas itu bukan menjadi solusi terbaik untuk semuanya. Suara terbanyak sering sekali disalah gunakan untuk meluluskan kepentingan golongan tertentu saja tanpa memikirkan golongan minoritas.

Prinsip musyawarah menghendaki agar hukum perundang-undangan dan kebijakan politik diterapkan melalui musyawarah di antara mereka yang berhak. Masalah yang diperselisihkan para peserta musyawarah harus diselesaikan dengan menggunakan ajaranajaran dan cara-cara yang terkandung alam alQur'an dan sunnah Rasul Allah SAW.

Prinsip musyawarah ini diperlukan agar para pembuat kebijakan dapat melaksanakn tugasnya dengan baik dan bertukar pikiran dengan siapa saja yang dianggap tepat guna mencapai perda syaria'h yang terbaik untuk semua.

\section{Penutup}

Perda syari'ah yang dibuat oleh pemerintah harus bisa mengakomodir nilai nilai fiqh siyasah didalamnya, sehinga hukum yang diterapkan nanti bisa mewujudkan kemaslahatan ditengah tengah masyarakat. Pengimplementasian nilai nilai tersebut merupakan suatu keharusan, sebagai bentuk pengejewantahan dari spirit keislaman. Perda syaria'h yang sudah menerapkan nilai nilai siyasah antara lain Perda Syari'ah yang berorientasi dan patuh terhadap syariat islam, Perda Syari'ah yang berorientasi pada kemaslahatan, Perda Syari'ah yang berorientasi pada nilai nilai keadilan dan persamaan hak, Perda Syari'ah yang menghindari unsur-unsur penganiayaan dan kedoliman, serta Perda syari'ah harus didasarkan pada Prinsip musyawarah.

\section{Pustaka Acuan}

Abd al Rahman Taj, Al Siyasah al Syar'iyyah wa al Fiqh al Islami (Matba'ah Dar al Ta'lif, 1953)

Abdul Wahab Khalaf, al siyasah syar'iyyah aw nidzham al dawlah al islamiyyah (Al Kaherah: Dar al Anshar, 1977)

Ahmad Sukardja, Hukum Tata Negara \& Hukum Administrasi Negara Dalam 
AL-IMARAH: Jurnal Pemerintahan dan Politik Islam

Vol. 4, No. 1, 2019

perspektif Fiqh Siyasah, (Sinar https://www.hukumonline.com, diakses pada Grafika, 2012)

Ahmad Warson Munawwir, kamus alMunawwar,( Surabaya : pustaka progressif)

Ali Syariati, Imamah dan Umamah, Terj. Afif Muhammad (Mizan, 1989)

Dani Muhtada, Ph.D, Makalah ini disampaikan dalam orasi ilmiah dalam rangka Dies Natalis VII Fakultas Hukum Universitas Negeri Semarang pada tanggal 4 Desember 2014 di Semarang.

Djazuli, Fiqh Siyasah, (Prenanda media, 2003) http://mediaindonesia.com, diakses pada tanggal 22 April 2019

http://www.gunromli.com, diakses pada tanggal 21 April 2019

http://www.muslimoderat.net, diakses 26 April 2019

https://news.detik.com, diakses pada tanggal 22 April 2019 tanggal 21 April 2019

Ibnu Hazm, Al-Ihkam fi Ushulil Ahkam, (Beirut: Darul Afaq, 2001), juz III

Imam al-mawardi, Al-Ahkam Ash-sulthaniyah ( sistem pemerintahan khalifah islam ), (Qisthi Prres; Jakarta)

Imam Bukhori, Shohih Bukhori, Maktabah Syamilah, Juz 6

Imam Muslim, Shohih Muslim, Maktabah Syamilah 14 G, Jus 4

Mujar Ibnu Syarif \& Khamami Zada, Fiqh Siyasah (Erlangga, 2008)

Reza Jurnaliston, Editor : Sabrina Asril, Artikel ini telah tayang di Kompas.com dengan judul "Grace Natalie Dilaporkan ke Bareskrim Polri terkait Penistaan Agama". https://nasional.kompas.com, diakses pada tanggal 22 April 2019

UU Pemerintahan Daerah Wahbah al-Zuhaylî, Ushûl al-Fiqh al-'Islâmî (Damaskus: Dâr al-Fikr, 2001) vol. 1 